\title{
Effect of Plant Density on Yield and Plant Characters of Twelve Corn Hybrids and Selections ${ }^{1}$
}

\author{
A. Sotomayor-Rios, C. Torres, and M. Ellis ${ }^{2}$
}

\begin{abstract}
Twelve corn (Zea mays L.) hybrids and selections were evaluated for yield and other plant characters at densities of 45,000 and 90,000 plants/ha. The study showed no yield advantage when densifies were increased to 90,000 plants/ha. Significant differences among entries were observed in time to midsilk, ear height, plant height, test weight, weight of 1000 kernels, rust severity, and yield. No population-density $\times$ entry interaction for these characters was observed. Significant differences between population densities and among entries were observed in diameter of the third internode and number of ears per plot. Hybrid Pioneer $304 \mathrm{C}$ had the highest yield; Mayorbela, the highest test weight; Diente de Caballo and Pioneer 306B, the highest 1000-kernel weight; and PR-Mp4 and Pioneer 306B, the lowest rust rating. The yields of Pioneer 304C, Pioneer 105A, Pioneer 306B, and PR-3 were very similar at both plant densities, while those of Pioneer 304B and PR-Mo2 were higher by 27 and $20 \%$, respectively, at the higher plant density. In six entries (PR-Mp4, DeKalb B-666, PR-Mo2 × Pr-3, Diente de Caballo, Mayorbela, and DeKalb B-660) yield was from 33 to $14 \%$ lower at the higher plant density.
\end{abstract}

\section{INTRODUCTION}

When corn hybrids, varieties, lines, or selections are being evaluated, it is essential to determine their differential response to population densities early in the improvement program. Although most reports tend to indicate a linear increase in yield with an increase in plant density, others have shown the opposite. According to Lang (2), varieties and hybrids of field corn tend to have a differential response to population densities, while Singh and Singh (6) noted that the lack of yield increases in various commercial hybrids at higher plant densities may be attributed to their long history of selection under medium to low densities.

In Puerto Rico, Vázquez (8) studied the effect of three population densities on yields of the local corn variety Mayorbela. He reported a linear increase in yield with an increase in plant population from 25,826 to 51,652 plants per hectare in irrigated plots. Singh and Singh (6) reported maximum grain yield, moisture content, plant height, and ear height when hybrid corn was grown at 100,000 plants/ha. Moll and Kamprath (3) evaluated three strains of corn resulting from recurrent selections at levels of $24,710,38,300$, and 49,420 plants/ha. They reported

\footnotetext{
${ }^{1}$ Manuscript submitted to Editorial Board September 10, 1979.

${ }^{2}$ Research Geneticist and Research Technician, Mayagüez Institute of Tropical Agriculture, Agricultural Research, Science and Education Administration, U.S. Department of Agriculture, Mayagüez, P.R. and Assistant Professor of Plant Pathology, Department of Crop Protection, University of Puerto Rico, Mayagüez, P.R. 00708.
} 
that increased population density resulted in greater yields in the improved strains, but the interaction between strain and density was not statistically significant. Rutger (4) evaluated seven single crosses and their component inbred lines at populations of $37,000,62,000$, and 86,000 plants/ha. Inbreds as a group were more population responsive than hybrids. A population increase from 37,000 to 86,000 plants/ha raised mean yields of inbreds $48 \%$ and mean yields of hybrids $37 \%$. In this experiment, there was a significant genotype $\times$ population interaction for yield. Rutger and Crowder (5) evaluated six corn hybrids at two locations for 3 years at densities of 40,50,60, 70,80, and 90 thousand plants per hectare. At the high populations, ear height was increased, and stalk diameter decreased. Highest grain yields were obtained at 70,000 plants/ ha.

This study was conducted to compare the effect of two population densities on the yield and several morphological characteristics of 12 corn hybrids and selections grown under tropical conditions.

\section{MATERIALS AND METHODS}

The 12 corn hybrids and selections included in the experiment were similar to those reported previously by Sotomayor-Ríos (6), except that the seed of local varieties Mayorbela and Diente de Caballo were obtained from the corn improvement program at Mayagüez Institute of Tropical Agriculture (MITA) after one cycle of selection.

The experiment was conducted at the MITA Isabela experiment farm in northwestern Puerto Rico. The farm is $128 \mathrm{~m}$ above sea level and the temperature ranges from $18^{\circ}$ to $31^{\circ} \mathrm{C}$. The soil is a Coto clay (Oxisol). Before planting, a complete fertilizer (15-5-10) was applied to all plots at $560 \mathrm{~kg} / \mathrm{ha}$. For control of soil nematodes and insects, carbofuran ${ }^{3}(2,3-$ dihydro-2, 2-dimethyl-7-benzofuranyl methylcarbamate) was band-applied at the rate of $6 \mathrm{~kg} / \mathrm{ha}$ to all rows with the fertilizer. Immediately after planting, propazine [2-chloro-4,6-bis(isopropylamino)-s-triazine] was applied to all plots at 2 to $3 \mathrm{~kg}$ of active ingredient per hectare to control weeds. Methomyl ( $S$-methyl $N$-[(methylcarbamoyl)oxy]thioacetimidate) was sprayed at $0.27 \mathrm{~kg}$ of active ingredient per hectare every 10 to 14 days to control insects.

The 12 corn entries (table 1) were grown at two population densities in a split-plot design with three replications. Populations of about 45,000 and 90,000 plants/ha were obtained by hand planting and thinning to one plant per hill in hills spaced at 22 and $11 \mathrm{~cm}$ apart, respectively. Each plot consisted of two rows $101 \mathrm{~cm}$ apart and $5 \mathrm{~m}$ long.

\footnotetext{
${ }^{3}$ This paper reports the results of research only. Mention of a pesticide in this paper does not constitute a recommendation by the USDA or the Agricultural Experiment Station of the University of Puerto Rico, nor does it imply registration under FIFRA.
} 
Data were taken on yield of corn (expressed as $\mathrm{kg} / \mathrm{ha}$ and adjusted to $15.5 \%$ moisture), number of ears per plot, test weight (expressed as $\mathrm{kg}$ / $\mathrm{hl}$ ), and 1000-kernel weight for plants in a $4-\mathrm{m}^{2}$ area of each plot. In addition, data were collected on ear height (soil surface to the topmost ear-bearing node), plant height (soil surface to the tip of the tassel), and diameter of the third internode, all for 10 consecutive plants per two-row plot. Time to midsilk and rust severity were recorded on a plot basis. Rust severity was evaluated on a scale of 0 (no lesions) to 5 (75 to 100\% of leaf area covered with lesions). Data were subjected to analysis of variance, and significant differences were identified with Duncan's multiple range test.

TABLE 1.-Yield and other plant characters of 12 corn entries planted on July 8, 1977, at Isabela, P.R. ${ }^{1}$

\begin{tabular}{llllllll}
\hline \multicolumn{1}{c}{ Entry } & $\begin{array}{c}\text { Time to mid- } \\
\text { silk }\end{array}$ & Ear height & $\begin{array}{c}\text { Plant } \\
\text { height }\end{array}$ & $\begin{array}{c}\text { Test } \\
\text { weight }\end{array}$ & $\begin{array}{c}\text { Weight of } \\
1000 \text { ker- } \\
\text { nels }\end{array}$ & $\begin{array}{c}\text { Rust rat- } \\
\text { ing }^{2}\end{array}$ & Yield \\
\hline & \multicolumn{1}{c}{ Days } & \multicolumn{1}{c}{ Cm } & $C m$ & $K g / h l$ & $G$ & & $K g / h \alpha$ \\
Pioneer 304C & $55.7 \mathrm{defg}^{3}$ & $128 \mathrm{cdef}$ & $243 \mathrm{ab}$ & $78.2 \mathrm{~b}$ & $282.7 \mathrm{~cd}$ & $3.0 \mathrm{~cd}$ & $6,229 \mathrm{a}$ \\
Pioneer 105A & $57.8 \mathrm{bcde}$ & $124 \mathrm{ef}$ & $237 \mathrm{ab}$ & $77.9 \mathrm{~b}$ & $268.4 \mathrm{de}$ & $3.0 \mathrm{~cd}$ & $5,252 \mathrm{~b}$ \\
Mayorbela & $55.0 \mathrm{efg}$ & $137 \mathrm{bcd}$ & $236 \mathrm{ab}$ & $81.4 \mathrm{a}$ & $276.2 \mathrm{de}$ & $3.3 \mathrm{bc}$ & $4,650 \mathrm{bc}$ \\
Diente de Caballo & $56.8 \mathrm{cdef}$ & $138 \mathrm{abc}$ & $242 \mathrm{ab}$ & $74.1 \mathrm{c}$ & $337.8 \mathrm{a}$ & $3.3 \mathrm{bc}$ & $4,489 \mathrm{bcd}$ \\
DeKalb B-666 & $59.8 \mathrm{bc}$ & $149 \mathrm{a}$ & $251 \mathrm{a}$ & $79.3 \mathrm{~b}$ & $291.0 \mathrm{~cd}$ & $2.6 \mathrm{~cd}$ & $4,468 \mathrm{bcd}$ \\
Pioneer 306B & $58.8 \mathrm{bcd}$ & $135 \mathrm{bcde}$ & $242 \mathrm{ab}$ & $74.5 \mathrm{c}$ & $319.5 \mathrm{ab}$ & $2.4 \mathrm{~d}$ & $3,899 \mathrm{cde}$ \\
PR-Mo2 & $54.0 \mathrm{fg}$ & $122 \mathrm{f}$ & $236 \mathrm{ab}$ & $77.6 \mathrm{~b}$ & $243.4 \mathrm{fg}$ & $4.2 \mathrm{a}$ & $3,675 \mathrm{cde}$ \\
PR-Mo2 $\times$ PR-3 & $53.1 \mathrm{~g}$ & $127 \mathrm{cdef}$ & $232 \mathrm{~b}$ & $74.6 \mathrm{c}$ & $257.2 \mathrm{ef}$ & $4.0 \mathrm{ab}$ & $3,538 \mathrm{de}$ \\
PR-Mp4 & $60.3 \mathrm{~b}$ & $125 \mathrm{def}$ & $243 \mathrm{ab}$ & $74.2 \mathrm{c}$ & $292.3 \mathrm{~cd}$ & $2.4 \mathrm{~d}$ & $3,445 \mathrm{de}$ \\
DeKalb B-660 & $63.5 \mathrm{a}$ & $138 \mathrm{abc}$ & $248 \mathrm{ab}$ & $73.8 \mathrm{c}$ & $229.8 \mathrm{~g}$ & $3.3 \mathrm{bc}$ & $3,280 \mathrm{e}$ \\
Pioneer 304B & $60.0 \mathrm{bc}$ & $122 \mathrm{f}$ & $215 \mathrm{c}$ & $78.7 \mathrm{~b}$ & $305.3 \mathrm{bc}$ & $3.1 \mathrm{~cd}$ & $3,137 \mathrm{e}$ \\
PR-3 & $57.3 \mathrm{bcdef}$ & $142 \mathrm{ab}$ & $247 \mathrm{ab}$ & $70.5 \mathrm{~d}$ & $236.0 \mathrm{fg}$ & $4.0 \mathrm{ab}$ & $3,012 \mathrm{f}$ \\
\hline
\end{tabular}

${ }^{1}$ Data are means for three replicate plots at each of two population densities.

${ }^{2}$ Rating scale: 1 (no infection) to 5 ( 75 to $100 \%$ of leaf covered with lesions).

${ }^{3}$ In each column, means followed by one or more letters in common do not differ significantly at $\mathrm{P}=0.05$, according to Duncan's multiple range test.

\section{RESULTS AND DISCUSSIONS}

The analysis of variance showed that there were significant differences among entries for time to midsilk, ear height, plant height, test weight, 1000-kernel weight, rust severity, and yield, but there was no populationdensity $\times$ entry interaction for these characteristics. Table 1 shows means across the two population densities for these characteristics.

Time to midsilk ranged from 53.1 to 63.5 days. Hybrid PR-Mo2 $\times$ PR3 was the earliest and DeKalb B-660 was the latest to reach midsilk. Pioneer $304 \mathrm{C}$, the best yielder, reached midsilk in about 56 days.

Ear height ranged from 122 to $149 \mathrm{~cm}$, and the average was $132 \mathrm{~cm}$. The greatest ear heights were observed in DeKalb B-666, PR-3, Diente 
de Caballo, and DeKalb B-660. Pioneer 304B and PR-Mo2 had the lowest ear height, $122 \mathrm{~cm}$.

Plant height ranged from 215 to $251 \mathrm{~cm}$. Most entires had statistically similar heights, but Pioneer 304B was significantly shorter than all other entries.

Test weight ranged from 70.5 to $81.4 \mathrm{~kg} / \mathrm{hl}$, and the average for all entires was $76.2 \mathrm{~kg} / \mathrm{hl}$. The highest test weight, that of the local variety Mayorbela, was significantly higher than those of the other entries. This finding is in agreement with results obtained when the same entries were planted on April 21, 1975, at Isabela, P. R. (7); Mayorbela had a higher test weight than the remaining 11 entries.

Weights of 1000 kernels ranged from 229.8 to $337.8 \mathrm{~g}$. The average 1000-kernel weight for all entries was $278.3 \mathrm{~g}$. The local variety Diente de Caballo and Pioneer 306B, produced the highest 1000-kernel weights 337.8 and 319.5 g, respectively. Entries PR-Mo2 × PR-3, PR-Mo2, PR-3, and DeKalb B-660 had 1000-kernel weights ranging from 229.8 to 257.2 g.

Rust ratings ranged from 2.4 to 4.2 . The average rating for all entries was 3.2. The best five entries, with ratings of 3.0 or less, were PR-Mp4, Pioneer 306B, DeKalb B-666, Pioneer 304C, and Pioneer 105A. Of all entries tested, PR-Mp4 and Pioneer 306B were the most resistant to rust, with values of 2.4. According to Craig et al. (1), PR-Mp4 "was resistant to Puccinia polysora and Helminthosporium maydis in Puerto Rico and to P. polysora in greenhouse tests in Mississippi." Entry PR-Mp4 should be of extreme value in the breeding and selection of corn genotypes for resistance to rust and southern leaf blight.

Yields ranged from 2,012 to $6,229 \mathrm{~kg} / \mathrm{ha}$. The most productive entry was Pioneer 304C, followed by Pioneer 105A, Mayorbela, and Diente de Caballo. Hybrid Pioneer 304C was consistently the most productive entry, as in previous tests conducted by Isabela (7). The local varieties Mayorbela and Diente de Caballo yielded 4,650 and 4,489 kg/ha, respectively, and were among the top producers.

The analysis of variance showed that there were significant differences between population densities and among entries in diameter of the third internode and number of ears per plot. Table 2 shows that the average diameter of the third internode was $2.18 \mathrm{~cm}$ at 45,000 plants/ha and 1.90 $\mathrm{cm}$ at 90,000 plants/ha. At 45,000 plants/ha the diameter of the third internode ranged from 1.95 to $2.30 \mathrm{~cm}$; all entries except Pioneer 304B had a mean diameter of more than $2.0 \mathrm{~cm}$. At 90,000 plants $/ \mathrm{ha}$, the diameter of the third internode ranged from 1.78 to $2.07 \mathrm{~cm}$; local varieties Mayorbela and Diente de Caballo, along with PR-Mo2, had the smallest diameter of the third internode. The diameter of the third internode was significantly different at 45,000 and at 90,000 plants/ha for all entries except DeKalb B-660, Pioneer 105A, and Pioneer 304B. 
The average number of ears per plot was 32.3 at 90,000 plants/ha and 25.6 at $45,000 /$ ha, an increase of $26.2 \%$ at the higher population density (table 2). The number of ears per plot at 45,000 plants/ha ranged from 20.7 to 28.7 , while at 90,000 plants/ha the range was from 26.0 to 40.3 ears. The number of ears per plot was significantly different at 90,000 and 45,000 plants/ha for the following entries: Mayorbela, Pioneer 105A, Pioneer 304C, PR-Mo2, DeKalb B-666, and PR-3.

A separate analysis was conducted to compare yield for each entry at each population density (table 3). The best producers, Pioneer $304 \mathrm{C}$ and Pioneer 105A, had similar yields at both population densities. Hybrid Pioneer $304 \mathrm{~B}$, however, showed a yield increase of $27 \%$ at the higher

TABLE 2.-Effect of plant density on diameter of the third internode and number of ears per plot of 12 corn entries planted on July 8, 1977, at Isabela, P. R.

\begin{tabular}{|c|c|c|c|c|}
\hline \multirow[b]{2}{*}{ Entry } & \multicolumn{2}{|c|}{ Diameter of the 3 rd internode } & \multicolumn{2}{|c|}{ Number of ears per plot } \\
\hline & $\begin{array}{l}45,000 \\
\text { plants/ha }\end{array}$ & $\begin{array}{c}90,000 \\
\text { plants / ha }\end{array}$ & $\begin{array}{c}45,000 \\
\text { plants/ha }\end{array}$ & $\begin{array}{c}90,000 \\
\text { plants/ha }\end{array}$ \\
\hline & $\mathrm{Cm}$ & & & \\
\hline DeKalb B-660 & $2.16_{t: 2}^{N S^{2}}$ & $2.07 \mathrm{a}$ & $25.7 \mathrm{ab}$ & $26.0_{e}^{N S}$ \\
\hline PR-3 & $2.26_{a}^{*}$ & $200 \mathrm{a}$ & $20.7 \mathrm{c}$ & $28.3_{\text {de }}^{*}$ \\
\hline Pioneer 105A & $2.16_{b}^{N S}$ & $1.98 \mathrm{a}$ & $28.7 \mathrm{a}$ & $39.7_{a b}^{*}$ \\
\hline PR-Mp4 & $2.28_{a}^{*}$ & $1.98 \mathrm{a}$ & $24.7 \mathrm{abc}$ & $27.3_{e}^{N S}$ \\
\hline Pioneer $306 \mathrm{~B}$ & $2.14 b_{b}^{*}$ & $1.94 \mathrm{a}$ & $26.0 \mathrm{ab}$ & $31.3_{\text {bcde }}^{N S}$ \\
\hline DeKalb B-666 & $2.30_{\alpha}^{*}$ & $1.91 \mathrm{a}$ & $26.0 \mathrm{ab}$ & $30.7_{c d e}^{*}$ \\
\hline Pioneer 304C & $2.29_{a}^{*}$ & $1.87 \mathrm{a}$ & $28.0 \mathrm{a}$ & $37.3_{a b c}^{*}$ \\
\hline Pioneer $304 \mathrm{~B}$ & $1.95_{b}^{N S}$ & $1.84 \mathrm{~b}$ & $21.7 \mathrm{c}$ & $26.3_{e}^{N S}$ \\
\hline PR-Mo2 $\times$ PR- 3 & $2.07 \frac{*}{b}$ & $1.84 \mathrm{~b}$ & $26.0 \mathrm{ab}$ & $32.0_{a b c d e}^{N S}$ \\
\hline Mayorbela & $2.16_{b}^{*}$ & $1.83 \mathrm{~b}$ & $28.3 \mathrm{a}$ & $40.3_{\alpha}^{*}$ \\
\hline Diente de Caballo & $2.20_{a}^{*}$ & $1.81 \mathrm{~b}$ & $26.7 \mathrm{ab}$ & $32.7_{a b c d e}^{N S}$ \\
\hline PR-Mo2 & $2.09 q_{b}^{k}$ & $1.78 \mathrm{~b}$ & $\underline{25.3 \mathrm{abc}}$ & $36.0_{a b c d}^{*}$ \\
\hline$\overline{\mathrm{X}}$ & 2.18 & 1.90 & 25.6 & 32.3 \\
\hline
\end{tabular}

${ }^{1}$ NS-Not significant (comparison between the two densities).

* - Significant at the 5\% level, according to Duncan's multiple range test.

${ }^{2}$ In each column, means followed by one or more letters in common do not differ significantly at $P=0.05$, according to Duncan's multiple range test.

plant density, although its yield was little more than one half that of the highest yielder (Pioneer 304C).

The yield of hybrids DeKalb B-666 and DeKalb B-660 decreased 28 and $14 \%$, respectively, when the plant density was increased. In local varieties Mayorbela and Diente de Caballo, yield decreases of 16 and $19 \%$, respectively, were observed at the higher plant density. The yield of population PR-Mo2 was $20 \%$ higher at the higher plant density, while that of PR-3 was the same at both densities. In contrast, the yield of hybrid PR-Mo2 $\times$ PR-3 was $28 \%$ lower at the higher plant density.

Although considerable changes in yield resulted from the increase in plant density from 45,000 to 90,000 plants/ha, only in two entries (DeKalb 
B-666 and PR-Mp4) were the changes (decreases) significant at the 5\% level.

Ear damage on all entries was similar at both population densities; the effect of rust did not appear to be responsible for the reductions in yield at the higher population density. In only one entry, Diente de Caballo, was the rust rating significantly higher at the higher plant density than at the lower plant density (4.0 vs. 2.7).

It is logical that corn yields should increase with increasing populations up to certain densities $(8,4)$. Beyond this, yields may level off or decrease. In this study, the yields of the best hybrids (Pioneer 304C and Pioneer 105A) were similar at densities of 45,000 plants/ha and 90,000 plants/ha. Although there was no increase in yield in these two hybrids at 90,000

TABLE 3.-Effect of population density on the grain yield of 12 corn entries planted on July 8, 1977, at Isabela, P. R.

\begin{tabular}{lccc}
\hline \multirow{2}{*}{ Entry } & \multicolumn{2}{c}{ Grain yield, kg/ha } & $\begin{array}{c}\text { \% change, } 90,000 \\
\text { vs. } 45,000\end{array}$ \\
\cline { 2 - 3 } & $\begin{array}{r}45,000 \\
\text { plants/ha }\end{array}$ & $\begin{array}{c}90,000 \\
\text { plants/ha }\end{array}$ & +2 \\
\hline Pioneer 304C & 6,178 & 6,280 & +1 \\
Pioneer 105A & 5,217 & 5,286 & -16 \\
Mayorbela & 5,050 & 4,250 & -19 \\
Diente de Caballo & 4,955 & 4,022 & $-28^{* 1}$ \\
DeKalb B-666 & 5,188 & 3,749 & +2 \\
Pioneer 306B & 3,866 & 3,932 & +20 \\
PR-Mo2 & 3,337 & 4,013 & -24 \\
PR-Mo2 × PR-3 & 4,031 & 3,044 & $-33^{*}$ \\
PR-Mp4 & 4,131 & 2,759 & -14 \\
DeKalb B-660 & 3,533 & 3,027 & +27 \\
Pioneer 304B & 2,768 & 3,505 & +0 \\
PR-3 & 2,008 & 2,015 & \\
\hline
\end{tabular}

${ }^{1}$ Significant at the 5\% level, according to Duncan's multiple range test.

plants/ha, apparently they tolerate such high densities better than the entries that were negatively affected by the higher population density. Perhaps more intraspecific competition occurred among entries that showed a yield decrease at the higher plant density than in Pioneer 304C and Pioneer 105A.

\section{RESUMEN}

Se observaron diferencias significativas entre 12 selecciones de maíz sembradas en densidades de 45,000 y 90,000 plantas/ha, en términos de los días transcurridos desde la siembra a los días a mitad de la floración, altura de la mazorca, altura de la planta, peso prueba $(\mathrm{kg} / \mathrm{hl})$, peso de 1,000 granos, infección de la roya y producción total. No se observó interacción para esos caracteres entre las densidades de siem- 
bra y las selecciones, pero sí para el diámetro del tercer entrenudo y número de mazorcas por parcela.

El experimento se llevó a cabo en la finca experimental del Instituto Mayagüezano de Agricultura Tropical del Departamento de Agricultura de los Estados Unidos, localizada en el noroeste de Puerto Rico.

Las 12 selecciones fueron: los híbridos 304B, 304C, 105A, DeKalb B660 y B-666; las selecciones de PR-Mp4, PR-Mo2, PR-3, y PR-Mo2 $\times$ PR-3; y las variedades nativas Diente de Caballo y Mayorbela.

El experimento se sembró siguiendo un diseño de bloques subdivididos, con tres repeticiones.

El híbrido Pioneer $304 \mathrm{C}$ fue el mejor productor $(6,229 \mathrm{~kg} / \mathrm{ha})$; la variedad local Mayorbela mostró tener el mejor peso prueba $(81.4 \mathrm{~kg} /$ hl); la variedad local Diente de Caballo y el híbrido Pioneer 304B el mejor peso de 1000 granos (338 y 335 g respectivamente). La selección PRMp4 y el híbrido Pioneer 306B mostraron la incidencia más baja de roya (2.4). El rendimiento de Pioneer 304C, Pioneer 105A, Pioneer 306B y PR-3 fue similar en las dos densidades de siembra, mientras que el de Pioneer 304B y PR-Mo2 fue 27 y 20\% más alto a 90,000 plantas/ha. Se observó que en seis selecciones (PR-Mp4, DeKalb B-666, PR-Mo2 $\times$ PR-3, Diente de Caballo, Mayorbela y DeKalb B-666) la producción fue de 33 a 14\% más baja a 90,000 plantas/ha. Los resultados de este estudio indican que en las 12 selecciones de maíz estudiadas, no hay mejora en rendimiento al aumentar la densidad de siembra a 90,000 plantas/ha.

\section{LITERATURE CITED}

1. Craig, J., Scott, G. E., Sprague, G. F., and Webster, O. J., 1976. Registration of PR-Mp1 and PR-Mp4 maize germplasm, Crop Sci. 16: 746.

2. Lang, A. L., Pendleton, J. W., and Dungan, G. H., 1956. Influence of population and nitrogen levels on yield and protein and oil contents of nine corn hybrids, Agron. J. 48: 284-9.

3. Moll, R. H. and Kamprath, E. J., 1977. Effects of population density upon agronomic traits associated with genetic increases in yield of Zea mays L., Agron. J. 69: 81-4.

4. Rutger, J. N., 1971. Effect of plant density on yield of inbred lines and single crosses of maize (Zea mays L.), Crop Sci. 11: 475-6.

5. - - and Crowder, L. V., 1967. Effect of high plant density on silage and grain yields of six corn hybrids, Crop Sci. 7: 182-4.

6. Singh, B. N. and Singh, J., 1977. Development and evaluation in an opaque-2 maize composite at three plant population densities, Crop Sci. 17: 515-6.

7. Sotomayor-Ríos, A., 1979. Performance of twelve corn hybrids and selections in three consecutive crops on the same site in the same year, J. Agri. Univ. P.R. 63: 170-9.

8. Vázquez, R., 1960. Effects of irrigation, nitrogen levels, and plant population on corn yields in Lajas Valley, P.R., J. Agri. Univ. P.R. 44: 121-37. 